\title{
Guidelines for the diagnosis, treatment and clinical monitoring of patients with juvenile and adult Pompe disease
}

\author{
Diretriz para o diagnóstico, tratamento e acompanhamento clínico de pacientes com \\ doença de Pompe juvenil e do adulto \\ Juan Clinton Llerena Junior', Osvaldo JM Nascimento², Acary Souza B Oliveira ${ }^{3}$, Mario Emilio T Dourado Junior \\ Carlo D Marrone 5 , Heloise Helena Siqueira ${ }^{6}$, Cláudia FR Sobreira7, Elza Dias-Tosta ${ }^{8}$, Lineu Cesar Werneck
}

\begin{abstract}
Pompe disease (PD) is a potentially lethal illness involving irreversible muscle damage resulting from glycogen storage in muscle fiber and activation of autophagic pathways. A promising therapeutic perspective for PD is enzyme replacement therapy (ERT) with the human recombinant enzyme acid alpha-glucosidase (Myozyme ${ }^{\circledR}$ ). The need to organize a diagnostic flowchart, systematize clinical follow-up, and establish new therapeutic recommendations has become vital, as ERT ensures greater patient longevity. A task force of experienced clinicians outlined a protocol for diagnosis, monitoring, treatment, genetic counseling, and rehabilitation for PD patients. The study was conducted under the coordination of REBREPOM, the Brazilian Network for Studies of PD. The meeting of these experts took place in October 2013, at L'Hotel Port Bay in São Paulo, Brazil. In August 2014, the text was reassessed and updated. Given the rarity of PD and limited high-impact publications, experts submitted their views.
\end{abstract}

Keywords: Pompe disease, glycogen storage disease type II, acid alpha-glucosidase, muscular weakness, dyspnea, GAA gene, rhGAA.

RESUMO

A doença de Pompe (DP) é uma doença grave, potencialmente letal, devida ao depósito de glicogênio na fibra musculare ativação devias autofágicas Tratamento promissor para a DP é a reposição enzimática com a enzima recombinante humana alfa-glicosidase ácida (rhAGA - Myozyme $\left.{ }^{\circledR}\right)$. A necessidade de organizar uma propedêutica diagnóstica, sistematizar o seguimento clínico e sedimentar as novas recomendações terapêuticas tornaram-se vitais à medida que o tratamento permite uma maior longevidade aos pacientes. Uma força-tarefa de clínicos experientes no manejo da DP foi constituída para elaborar um protocolo para o diagnóstico, acompanhamento clínico, tratamento, aconselhamento genético, entre outras considerações voltadas ao paciente adulto. $O$ estudo foi realizado sob a coordenação da Rede Brasileira de Estudos da Doença de Pompe (REBREPOM). Diante da raridade da DP e escassez de trabalhos de alto impacto de evidência científica, os especialistas emitiram suas opiniões.

Palavras-chave: doença de Pompe, doença de depósito de glicogênio tipo II, alfa-glicosidade ácida, debilidade muscular, dispneia, gene GAA, GAA recombinante humana.

\section{DATA COLLECTION}

This study began in 2013 with a web search on the databases Medline, Embase and LILACS using the following keywords: "Glycogen Storage Disease Type II" [MeSH] OR "Lysosomal Storage Diseases" [MeSH] OR "Pompe Disease" [MeSH] OR "Enzymatic Replacement Therapy" [MeSH]. We obtained 255 studies, 123 for childhood onset

${ }^{1}$ Instituto Fernandes Figueira (FIOCRUZ), Departamento de Genética Médica, Rio de Janeiro RJ, Brazil;

Universidade Federal Fluminense, Departamento de Neurologia e NeuroUPC, Rio de Janeiro RJ, Brazil;

${ }^{3}$ Universidade Federal de São Paulo, Departamento de Neurologia, Sao Paulo SP, Brazil;

4Universidade Federal do Rio Grande do Norte, Departamento de Neurologia, Caiaco RN, Brazil;

${ }^{5}$ Clínica Marrone, Porto Alegre RS, Brazil;

${ }^{6}$ Universidade de Cuiabá, Departamento de Neurologia, Cuiaba MT, Brazil;

${ }^{7}$ Universidade de São Paulo, Departamento de Neurociências, Ribeirao Preto SP, Brazil;

${ }^{8}$ Hospital de Base do Distrito Federal, Serviço de Neurologia, Brasilia DF, Brazil;

9Universidade Federal do Paraná, Serviço de Doenças Neuromusculares, Curitiba PR, Brazil.

Correspondence: Osvaldo J M Nascimento MD, PhD, FAAN; Universidade Federal Fluminense, Departamento de Neurologia; Rua Siqueira Campos, 53/1204; 22031-171 Rio de Janeiro RJ, Brasil; E-mail: osvaldo_nascimento@hotmail.com

Conflict of Interest: There is no conflict of interest to declare.

Received 12 May 2015; Received in final form 05 September 2015; Accepted 25 September 2015. 
(< 18 years old) Pompe Disease (PD) and 132 for adult onset PD. We then selected studies based on their strength of recommendation and quality of evidence. In August 2014, a new search identified 329 studies published between the years 2010 and 2014.

Strength of recommendation and quality of evidence: A. experimental studies or strong observational studies (randomized);B. experimental studies or other observational studies (case-control); C. Case reports (uncontrolled studies); D. expert opinion without critical evaluation, based on consensus, physiological studies or animal models.

\section{PD DEFINITION}

Pompe disease (PD) (OMIM \# 232300), also known as glycogen storage disease type II, is a rare lysosomal storage disease classified as an inborn error of metabolism ${ }^{1}$. It is caused by partial or complete deficiency in the activity of the acid alpha-glucosidase enzyme (GAA) (EC 3.2.1.20), which is essential for the degradation of lysosomal glycogen into glucose. This deficiency causes a progressive accumulation of glycogen in the cells of various tissues, manifesting in multisystem form, predominantly in the skeletal, cardiac and smooth muscle systems ${ }^{1}$.

PD has been defined as a low/abnormal activity of the GAA enzyme in asymptomatic or symptomatic individuals and/or presence of two pathogenic mutations in the $G A A$ gene $^{2}(\mathrm{~B})$.

\section{EPIDEMIOLOGY}

The frequency of PD is quite variable (Table1). Recently, through a blind analysis of 100,000 samples obtained from neonatal screening through mass tandem spectrometry, Scott et al. ${ }^{3}$ (B) identified, among other lysosomal diseases (Fabry and mucopolysaccharidosis type 1 - MPS I), an incidence of PD about 1/27,800 of the newborns.

Table 1. Pompe disease incidence in different populations.

\begin{tabular}{lcc}
\hline Population (Year) & Incidence & Reference \\
\hline Afro-Americans (2001) & $1: 14,000$ & 1 \\
\hline Dutch (1999) & $\begin{array}{c}1: 40,000 \text { combined } \\
1: 138,000 \text { early onset } \\
1: 57,000 \text { adults }\end{array}$ & 4 \\
& $\begin{array}{l}1: 40,000 \text { combined } \\
\text { Americans (1998) }\end{array}$ & 5 \\
\hline $\begin{array}{l}\text { European Descendents } \\
\text { (1998) }\end{array}$ & $\begin{array}{c}1: 100,000 \text { early onset } \\
1: 60,000 \text { adults }\end{array}$ & 5 \\
\hline Australia (1999) & $1: 145,000$ & 6 \\
Portugal (2004) & $1: 600,000$ & 7 \\
\hline Taiwan (2014)* & $\begin{array}{c}1: 18.221 \text { combined } \\
\text { 1:52.538 early onset }\end{array}$ & 8 \\
\hline *neonatal screening. & $1: 27.866$ late onset & \\
\hline
\end{tabular}

On the other hand, a study conducted in 104 muscle biopsies from asymptomatic or oligosymptomatic (fatigue, cramps, myalgia) patients, with increased serum $\mathrm{CK}$, normal physical examination and no statin exposure, PD in juvenile and adults (PDJ-A) was identified in $3.8 \%$ of patients ${ }^{4}(\mathrm{C})$. Werneck et al. ${ }^{5}$, in a particular study of symptomatic cases, reviewed 4,500 muscle biopsies performed over a period of 33 years in a reference center for neuromuscular diseases in Brazil and identified 19 cases of PD, 10 cases of early onset PD and 9 cases of PDJ-A (C).

\section{PATHOPHYSIOLOGY}

PD is an autosomal recessive disease caused by pathogenic mutations in both copies of the gene that encodes the enzyme $G A A$. Hundreds of mutations have been identified in the GAA gene (http://www.pompecenter.nl/).

$\mathrm{PD}$ severity and age of symptom onset are related to the level of residual activity of the GAA enzyme. Early onset infantile PD results from a complete deficiency of the enzyme (activity < 1\%), while late onset PD (juvenile or adult) results from partial deficiency of GAA (1-30\%). Onset may occur as early in childhood or as late as at the sixth decade of life $e^{6,7}(\mathrm{~B})$.

The cause of PD is the progressive accumulation of intralysosomal glycogen due to the inability of the cell to breakdown the lysosomal glycogen into glucose. As a result, lysosomal membranes rupture, causing leakage of hydrolytic material into the cytoplasm with impairment of the muscle contractile unit ${ }^{1}$. There is also saturation of autophagic pathways during the pathophysiological $\operatorname{process}^{8}(\mathrm{C})$.

\section{SYMPTOMS AND SIGNS OF JUVENILE AND ADULT POMPE DISEASE (TABLE2)}

The clinical manifestations vary according to the patient's age, the rate of disease progression and the extent of organ involvement, and may result in irreversible motor impairment $^{9,10}(\mathrm{~B})$. The most common manifestation in adults is progressive muscle weakness simulating the muscular dystrophies. Most patients present weakness of the proximal and axial musculature, especially in the lower $\operatorname{limbs}^{14,15}(\mathrm{C})$. Weakness of the paraspinal muscles of the lower back, weak and protruding abdominal muscles, weakness of facial muscles and eyelid ptosis and tongue paralysis reinforce the clinical suspicion ${ }^{11,12,13}$.

The presence of dysphonia and dysphagia reflects the disease's bulbar impairment ${ }^{14}$, and involvement of the auditory system has also been reported ${ }^{15}$.

\section{GUIDED PHYSICAL EXAMINATION}

The physical examination in PDJ-A should focus on the muscular and respiratory systems. 
Pain and fatigue are regularly reported symptoms ${ }^{16}$. Diaphragm muscle weakness occurs early on in PD, and may precede limb or axial muscle weakness ${ }^{17}(\mathrm{~B})$.

In a patient that is asymptomatic or has muscle fatigue, the following signs and symptoms may be seen in PDJ-A:

- compensatory rotation of the body to rise from the ground ${ }^{11}(\mathrm{C})$;

- morning headache; narcolepsy ${ }^{17}(\mathrm{C})$;

- myopathy with myotonic paroxystic discharges (as seen in EMG) without clinical myotonia ${ }^{18}(\mathrm{C})$;

- CKlevels that do not exceed 15 times the normal value ${ }^{4}(\mathrm{C})$;

- increased transaminases without liver disease in asymptomatic or oligosymptomatic individuals ${ }^{19}(\mathrm{C})$;

- vacuolar myopathy assessed by muscular biopsy ${ }^{5}(\mathrm{C})$;

- MRI imaging with evidence of muscle atrophy or diffusion abnormalities during the process of fat suppression in the posterior thigh, abdominal or paravertebral muscles ${ }^{20}(\mathrm{C})$;

- cardiac arrhythmia associated with skeletal muscle weakness $^{21}(\mathrm{C})$;

- loss or rigidity of aortic compliance and hypertension ${ }^{22}(\mathrm{C})$;

- $\quad$ idiopathic stroke with middle cerebral artery aneurysms ${ }^{23}(\mathrm{C})$;

- $\quad$ post-pubertal adolescent or adult idiopathic scoliosis ${ }^{24}(\mathrm{C})$;

- $\quad$ rigid spine syndrome ${ }^{25}(\mathrm{C})$.

Table 2. Summary of the main clinical features of adults with Pompe disease $2,8,9$

\begin{tabular}{|c|c|}
\hline Organ or system & Clinical features \\
\hline Skeletal muscle & $\begin{array}{l}\text { Weakness of the pelvic and shoulder girdles } \\
\text { Myalgia } \\
\text { Exercise intolerance and fatigue } \\
\text { Axial muscle weakness: abdominal and } \\
\text { lumbar paraspinal muscles } \\
\text { Contractures and deformities ("idiopathic" } \\
\text { rigid spine) }\end{array}$ \\
\hline $\begin{array}{l}\text { Other muscles } \\
\text { (facial, oral) }\end{array}$ & $\begin{array}{l}\text { Tongue weakness } \\
\text { Macroglossia } \\
\text { Eyelid ptosis } \\
\text { Dysphonia } \\
\text { Dysphagia } \\
\text { Difficulty in chewing }\end{array}$ \\
\hline Lung & $\begin{array}{l}\text { Dyspnea on exertion } \\
\text { Orthopnea } \\
\text { Acute respiratory failure } \\
\text { Central and obstructive sleep apnea } \\
\text { Sleep disorder - morning headache }\end{array}$ \\
\hline Other systems & $\begin{array}{l}\text { Hepatomegaly } \\
\text { Ectasia of the cerebral arteries with vascular } \\
\text { aneurysm } \\
\text { Wolf-Parkinson - White syndrome } \\
\text { Postprandial pain in the elderly } \\
\text { Chronic diarrhea } \\
\text { Hyperlordosis and/or scoliosis }\end{array}$ \\
\hline Outcomes & $\begin{array}{l}\text { Adults with PD have a respiratory disturbance } \\
\text { often before the muscle weakness } \\
\text { Slow progression of motor weakness } \\
\text { Disease progression with stability for long periods } \\
\text { Patients with early respiratory insufficiency may } \\
\text { have a worse prognosis }\end{array}$ \\
\hline
\end{tabular}

\section{DIFFERENTIAL DIAGNOSIS}

Early involvement of respiratory muscles anticipating muscle weakness may differentiate PDJ-A from other neuromuscular diseases ${ }^{17}$.

Table 3 lists the diseases considered in the differential diagnosis of PDJ-A.

\section{DIAGNOSTIC LABORATORY METHODS FOR JUVENILE AND ADULT POMPE DISEASE}

\section{Dry blood spot on filter paper as a screening test for PD}

The introduction of the dry blood spot (DBS) test on filter paper into clinical practice provided a simple and reliable laboratory method for screening patients with suspicion of $\mathrm{PD}^{26,27}$ (Table 4).

Whenever the suspicion of PD persists, the test should be repeated, and additional diagnostic methods should be employed (Table 4). As all screening tests, suspected cases require a confirmation by at least one diagnostic test ${ }^{26,27}(\mathrm{~B}, \mathrm{C})$. DBS pre-analytical problems may result in false-negative and/or false positive screening results ${ }^{26}$.

\section{Laboratory diagnosis for childhood and adult PD}

Upon a positive DBS screening test for PD, additional diagnostic evidence should be obtained by measuring the

Table 3. Differential diagnosis in Pompe disease $2 . a$ www.musclegenetable.org

\begin{tabular}{|c|c|}
\hline Neuromuscular disorder & Disorder \\
\hline \multirow[t]{4}{*}{ Muscular dystrophies } & Girdle muscular dystrophies \\
\hline & $\begin{array}{l}\text { Duchenne e Becker muscular } \\
\text { dystrophies }\end{array}$ \\
\hline & Miofibrilar myopathy \\
\hline & Myotonic Distrophy type 2 \\
\hline Inflammatory myopathies & Polymyositis \\
\hline \multirow[t]{5}{*}{ Congenital myopathies ${ }^{b}$} & Nemaline myopathy \\
\hline & $\begin{array}{l}\text { Central Core or Multiminicore } \\
\text { myopathy }\end{array}$ \\
\hline & Centronuclear myopathy \\
\hline & Danon disease \\
\hline & $\begin{array}{l}\text { X-linked myopathy with na } \\
\text { excesso f autophagy }\end{array}$ \\
\hline \multirow[t]{4}{*}{ Metabolics myopathies } & $\begin{array}{l}\text { Glycogen debranching enzyme } \\
\text { deficiency (Glycogenosis Type IIla } \\
\text { ou IIlb - Cori or Forbe disease) }\end{array}$ \\
\hline & $\begin{array}{l}\text { Glycogen branching enzyme } \\
\text { deficiency (Glycogenosis Type } \\
\text { IV - Andersen Disease) }\end{array}$ \\
\hline & McArdle syndrome \\
\hline & Mitocondrial myopathies ${ }^{c}$ \\
\hline Motor neuron disease & Spinal mucular atrophy Types 2 e 3 \\
\hline Neuromuscular junction disease & $\begin{array}{l}\text { Miastenia gravis } \\
\text { Congenital myastenic syndromes }\end{array}$ \\
\hline
\end{tabular}


Table 4. Recommendations for diagnostic tests in Pompe disease in adults ${ }^{26}$

Screening Test - DBS - "dried blood spot" on filter paper to perform enzymatic activity analysis of acid $\alpha$-glucosidase (GAA) ${ }^{a, b}$

"Gold standard" Diagnostic Test - in fibroblasts or muscle tissue for acid $\alpha$-glucosidase (GAA) enzymatic assay

Diagnostic Test - molecular analysis of the GAA gene ${ }^{b}$

Diagnostic Test in DBS - GAA activity in lymphocytes and/or leucocytes

an clinical practice, the definitive diagnosis of Pompe disease is now being based on the molecular analysis of the GAA gene for the presence of two pathogenic allelic mutations (www.pompecenter.nl); ' Genetic variants of the GAA gene [c. (1726A; 2065A)] have been identified, especially in Asian populations; the combination with a pathogenic GAA allelic pathogenic mutation reduces the GAA enzyme activity on enzymatic assays specially from filter papers, which leads to false positives results considering neonatal screening programs. Such individuals are not diagnosed with PD and are instead classified as being pseudo-deficient individuals for the GAA enzyme.

amount of GAA activity in leukocytes or fibroblasts ${ }^{26}$ and/or by conducting $G A A$ genotyping in search of two pathogenic GAA mutations ${ }^{2}$ (Table 4).

Whenever there is any doubt in the DBS test and clinical suspicion persists, patients with symptoms suggestive of PD should have their GAA activity measured once again by the same laboratory that performed the first analysis. If the patient is negative for the GAA enzyme assay in leukocytes and the possibility of PD persists, diagnosis should proceed with at least one of the following three options:

a) DNA analysis searching for pathogenic mutations in the $G A A$ gene $^{2}$; or

b) Muscle biopsy evaluation, to assess the presence of abnormal accumulation of glycogen with vacuolar myopathy ${ }^{5,29}$ (B), although not specific for PD; or

c) Fibroblast culture from skin biopsy to test for $G A A$ activity ${ }^{26}$.

\section{GENETIC ASPECTS OF JUVENILE AND ADULT POMPE DISEASE PATIENTS - GENOTYPE-PHENOTYPE CORRELATION AND CRIM STATUS}

The enzymatic deficiency in PD is caused by pathogenic mutations in both alleles of the $G A A$ gene. Mutations can be similar (homozygote); or, different (compound heterozygote); however, both within the GAA gene. The most common mutation observed in PDJ-A patients, including Brazilians, is the intronic alteration c.-32-13 T > G (IVS1-13T > G), which is observed in more than two-thirds of the patients worldwide $\mathrm{e}^{7,30}$. The type and combination of these mutations will determine the amount of residual GAA activity in the cells ${ }^{6,7}$.

The combination of two severe mutations leads to a complete lack of GAA protein and, as a consequence, an extremely low residual GAA activity $(<1 \%)$; such genotype is associated with the severe early onset $\mathrm{PD}^{31}$. From an immunological point of view, these individuals are classified as CRIM (Cross Reactive Immunological Material) negative patients. CRIM negative individuals who undergo ERT with GAA ( rhGAA enzyme) may have severe reactions to the infusion, as well as the production of high titers of IgG antibodies ${ }^{32}$. (B)

On the other hand, any other combination of mutations, being at least one of then considered a "milder" mutation, such as the classic c. -32-13 T > G, enzyme production will occur, even if abnormally, resulting in different levels of residual
GAA activity of up to $30 \%$ of the normal value ${ }^{6,7}$. Patients with at least one mild mutation constitute most cases of juvenile and late-onset PD and present a clinical phenotype with a slower progression ${ }^{1,7}$. From an immunological standpoint, these patients are classified as CRIM positive ${ }^{31}$, and generally, will probably not be prone either to severe adverse reactions to Enzyme Replacement Therapy (ERT) with the rhGAA enzyme or sustain high titers of antibodies ${ }^{33}(\mathrm{~B})$.

\section{ENZYME REPLACEMENT THERAPY IN PATIENTS WITH CHILDHOOD AND ADULT POMPE DISEASE}

Until recently, treatment for PD consisted only in palliative care. In a natural history study of 255 patients with DPJ-A, disease severity assessed by the need for a wheelchair or dependence on mechanical ventilation showed that progression to wheelchair use increased, on average, $13 \%$ each year in patients without ERT treatment ${ }^{34}(\mathrm{~B})$.

In 2007, the commercial use of the $r h G A A$ enzyme was approved for early onset PD patients; and, in 2010, for the late-onset PD presentation. In the 18-month clinical trial conducted with the $r h G A A$ enzyme in the late-onset PD form, there was an increase in the six minute walk test as well as stabilization of their pulmonary function ${ }^{35}(\mathrm{~A})$.

The goals of $r h G A A$ enzyme therapy depend on the stage of disease progression ${ }^{35,36}(\mathrm{~B})$, and include:

- To slow down, stabilize or reverse disease progression;

- To reduce comorbidities and increase survival;

- To improve mobility, preserve motor function, delay the need for walking assistance, and promote motor gains;

- To improve or maintain respiratory function, thus preventing the need for respiratory assistance;

- To improve or preserve patient independence and quality of life.

A systematic review ${ }^{37}$ of the clinical and therapeutic outcomes of ERT with the $r h G A A$ enzyme after one year of treatment in 251 patients with the PD-A presentation and 27 patients with juvenile PD yielded the following findings:

- six-minute walk test: $78 \%$ increased the distance covered, $8 \%$ maintained the same distance, and $4 \%$ decreased the distance;

- Motor Performance: 10\% improved, one bedridden patient was able to sit up, three patients in wheelchairs 
were able to walk a few times a day, and three patients no longer required wheelchairs;

- Forced Vital Capacity (FVC) (127 patients): 53\% improved and $33 \%$ worsened;

- Ventilatory support (58 patients): 70\% improved.

The delay between the first symptoms of the disease, the definitive diagnosis of DPJ-A, and the beginning of ERT, have shown an inverse relationship with the therapeutic prognosis and clinical outcomes desired ${ }^{38}$.

\section{Practical instructions for enzyme replacement therapy}

Currently, there is only one commercially available product for ERT with the $r h G A A$ enzyme for PD (Reg MS: 1.2543.0020.001-0.)

Regardless of the PD type, treatment with the $r h G A A$ enzyme should be started at a reference hospital where it would be possible to intervene in the event of any adverse event related to the venous infusion ${ }^{39}$. It is also essential to inform the family about the goals of ERT, the treatment expectations based on the stage of the disease, and the guidelines for clinical follow-up and evaluation ${ }^{28,40}$.

Health professionals should address the difficulty of predicting the response to long-term ERT treatment and prioritize factors that could potentially influence treatment response, such as respiratory function and muscle involvement. The multidisciplinary team should be instructed regarding these issues. We recommend training the nursing and pharmacy staff on the handling of the drug prior to the first infusion, and provide specific guidance to physicians and the infusion center staff. One should always record the occurrence of any adverse event, whether or not they are associated with ERT. The dose of $r h G A A$ enzyme for ERT should follow the manufacturer's recommendations. The current standard dose of Myozyme is a minimum four-hour infusion of $20 \mathrm{mg} / \mathrm{kg}$ every 15 days.

While adverse events in patients withPDJ-A are considered rare (see Genotype-Phenotype correlation) ${ }^{39}$, infusion-related reactions generally require medical intervention. These reactions are usually mild to moderate and respond positively to a reduction in infusion rate.

The most serious and rarely observed side effects of ERT with $r h G A A$ are life-threatening anaphylactic reactions, serious allergic reactions and immune-mediated reactions. Such events are also rare in late-onset PD because patients are CRIM positive ${ }^{32}$.

\section{Inclusion and exclusion criteria for enzyme replacement therapy (Table 5)}

The heterogeneity of symptoms and signs present in PD patients (Table 2), the intra-familial variability and different stages of PD have led to the characterization of different patient groups and created a clinical dilemma of when to put a patient on ERT with $r h G A A$. The groups currently are identified as newborns identified via newborn screening; asymptomatic patients with or without clinical signs of the disease $^{41}$; symptomatic PD patients ${ }^{36}$ and patients with severe $\mathrm{PD}^{9,10}$ (Table 5).

Table 5. Summary of recommendations for ERT treatment based on the stage and severity of Pompe disease.

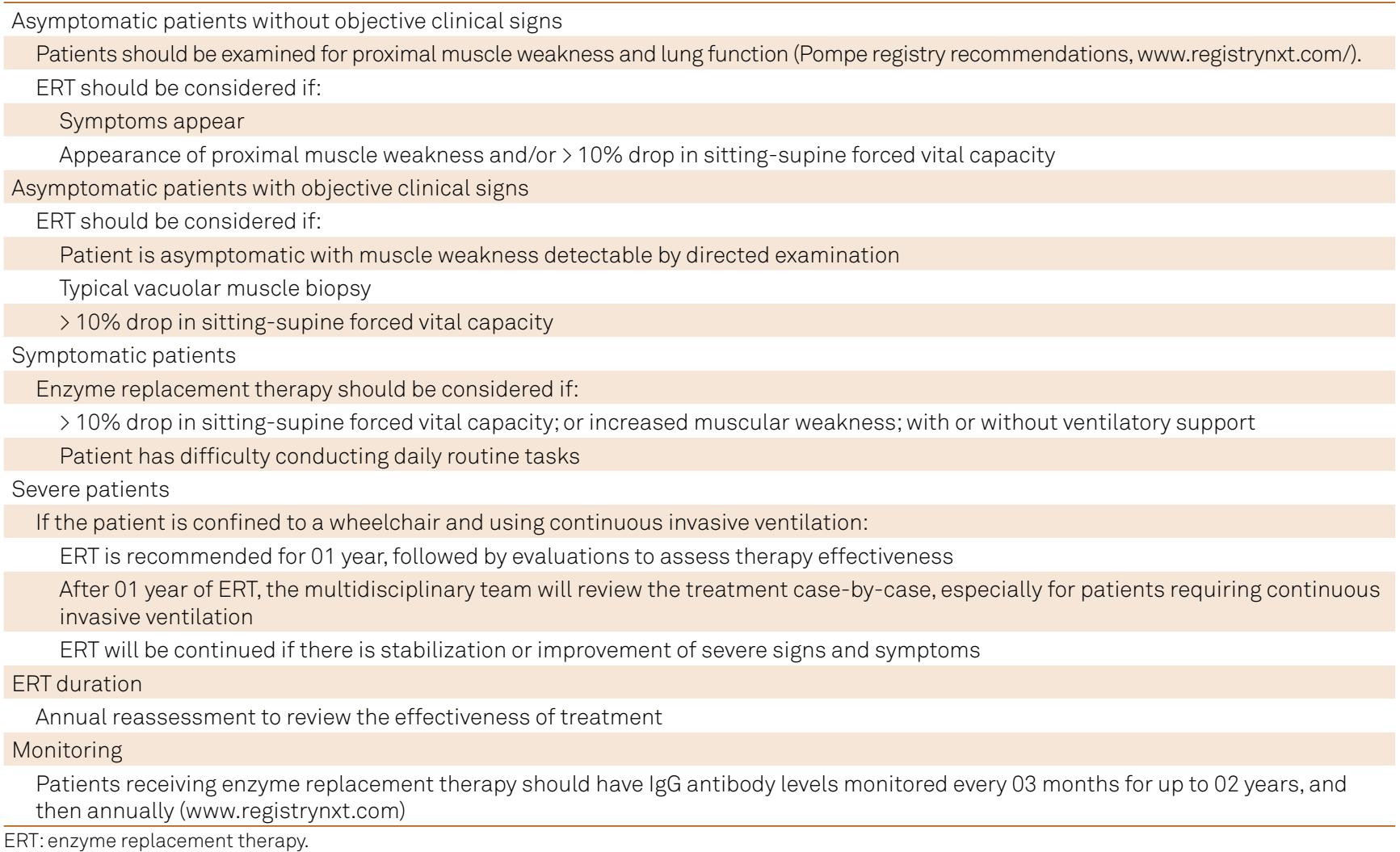


In most cases of PDJ-A, the duration of $r h G A A$ treatment is indefinite. Thus, the treatment goals, the timing of clinical evaluations, and quality oflife studies (SF-36- www.sf-36.org/), may support the multidisciplinary team in clinical management decisions ${ }^{28,40,41}$. It appears that major improvement of muscle strength and respiratory function with ERT is not common in patients with late-onset Pompe's disease ${ }^{35}$. The termination of ERT can be a very difficult task, and there is no consensus regarding this topic except on a case-by-case discussion. The involvement of family members in such decisions is very important ${ }^{28,40}$ (Table 5).

\section{Monitoring and laboratory tests for enzyme replacement therapy}

PD patients on ERT with the rhGAA enzyme will make seroconversion in $95 \%$ of cases becoming $\operatorname{IgG}$ positive ${ }^{39}$. However, exceptionally high titers of persistent antibodies may occur and this can activate the complement cascade and neutralize the rhGAA enzyme ${ }^{32}$. In these circumstances, there is a decline of the therapeutic response to ERT (walking, lung function, SF-36) and adverse events associated to ERT may be observed ${ }^{32}$ (B). Currently, immune modulation and immune suppression protocols, in an attempt to reduce neutralizing antibodies against $r h G A A$, have been successfully applied in infantile onset $\mathrm{PD}$ patients with high sustained IgG antibodies ${ }^{42}$. Patients with PDJ-A are CRIM-positive and therefore are less likely to have such serious immunological reactions ${ }^{32}$. The concentrations of $\operatorname{IgG}$ and $\operatorname{IgE}$ antibodies, tryptase and complement activation studies need to be monitored based on the Doctor's Guide to Clinical Management of Pompe Disease.

Hypersensitivity to the drug should be considered an absolute contraindication to the use of ERT with $r h G A A$ enzyme.

\section{Pregnancy, lactation and enzyme replacement therapy}

Since the introduction of ERT, a growing number of women with metabolic diseases have been able to reach reproductive life and become pregnant. Pregnant women with Gaucher, Fabry and (more recently) Pompe disease, are creating a new clinical challenge for obstetricians $s^{43,44}$.

Until 2014, two cases of pregnant women with PD receiving ERT have been published ${ }^{44,45}$. Recently, Karabul et al. ${ }^{46}$ collected information on 52 women with PD-A and 125 pregnancies through a retrospective self-administered questionnaire sent to Pompe associations in England and Germany, as well as neuromuscular disease centers in Germany. Pregnant women undergoing ERT not exhibited a reduction in mobility and muscle function, and many asymptomatic patients experienced their first PD symptoms during pregnancy ${ }^{51}$. Many pregnant women also used wheelchairs intermittently. A decrease in lung function, as measured by spirometry, was common to all pregnant women, including those undergoing ERT. Nonetheless, the reported experiences were highly favorable to the use of ERT during pregnancy, anesthesia, postpartum, newborn health, lactation and recovery of prepregnancy clinical status ${ }^{46}$. FDA classification/pregnancy category B (http://www.accessdata.fda.gov).

Pregnant women with neuromuscular diseases and vital capacity $<11$ (normal reference $=4.51$ ) should be warned of the high risk of complications during pregnancy and childbirth. In case of maternal hypoxia with $\mathrm{O}_{2}$ saturation under $85 \%$, the rate of live births is only $12 \%$. The recommendation for pregnant women with PD is a cesarean delivery under local instead of general anesthesia ${ }^{47}$.

\section{MULTIDISCIPLINARY CLINICAL MONITORING}

Due to the predominance of muscular signs and symptoms, PDJ-A is primarily a neuromuscular disease. Thus, the neurologist's role is crucial in coordinating the clinical decisions made by the professional health team ${ }^{2,28,40}$.

The ICD-10 classification (E74.0) may not accurately describe the functional impairment and disability associated with PD, since these patients vary in their degree of functionality. The International Classification of Functioning, Disability and Health (ICF) ${ }^{48}$ provides more meaningful information and data for clinical purposes (Table 6).

A study of 210 adults with PD using the Quality of Life Scale (SF-36) survey ${ }^{34}$ highlights the impact of the disease on patients' ability to work, perform household activities and move independently outside of their home. Progressive disability also increases the dependence of family members and other supportive care in the management of PD patients.

We recommend using disability scales (the Rotterdam study), visual analog scales for measuring pain, and the SF-36.

Table 6. Classification of functioning, disability and health (ICF) for adult Pompe disease (2003). www.who.int/classification/icf

\begin{tabular}{ll}
\hline Code & Domain \\
\hline b134 & Sleep functions \\
b3100 & Voice production \\
b445; s430 & $\begin{array}{l}\text { Respiratory muscle functions; structure of the } \\
\text { respiratory tract }\end{array}$ \\
b455 & Exercise tolerance functions \\
b510 & Food intake functions \\
b525 & Defection functions \\
b530 & Weight maintenance functions \\
b730 & Muscle strength functions \\
d230 & Performing daily routines \\
d450 & Walking \\
d460 & Moving through different locations \\
d598 & Self-care \\
d640 & Performing household chores \\
e120 & Products and technologies to facilitate mobility \\
& and/or transport the person indoors and outdoors \\
\hline
\end{tabular}




\section{Functional rehabilitation of skeletal muscles}

Skeletal muscle involvement in PD is characterized by progressive weakness, poor posture and compensatory movement patterns. Table 7 lists the main recommendations for patients with PDJ-A regarding the maintenance of functional muscle activity.

The assessment of skeletal muscle function, strength and structure should include:

- Timed functional tests and mobility scales: 6-minute walk test; 4-step ascent and descent staircase test ${ }^{40,49}$;

- Manual or quantified evaluation of muscles strength $(\mathrm{MRC} \text { scale })^{49}$;

- Evaluation of tongue strength ${ }^{13}$;

- Magnetic resonance imaging of the skeletal muscle, including tongue, paraspinal and thighs ${ }^{20}$.

\section{Active physical activity}

Recent evidence shows that people with carbohydrate processing disorders can benefit from light $\operatorname{exercise}^{50}(\mathrm{C})$. People who are physically fit are better able to use alternative sources of fuel for energy. Excessive strain in PDJ-A can cause muscle injuries; therefore, all exercise programs should be supervised by a professional familiar with PD (Table 6).

Therapeutic exercise should start lightly, be interspersed with rest periods, and follow a gradual increase in intensity until it reaches $60-75 \%$ of maximum effort in three to five days per week ${ }^{50}$ (B). Strenuous or eccentric physical therapy exercises should be avoided, especially in proximal muscles, flexors and abductors of the lower limbs (Nascimento, Siqueira and Barone, personal observation, 2014).
Optimization of the biomechanical advantages of movement:

- Provide positioning and support to increase biomechanical advantage;

- Save energy;

- Optimize the effects of gravity;

- Consider positions that improve the muscle length-tension relationship

- Minimize muscle contracture.

\section{Prevention of secondary musculoskeletal deficits (Table 7)}

Secondary musculoskeletal impairments can be prevented by following the principles of biomechanics to counteract deforming forces. This is done by applying light pressure, stretching, practicing posture correction, performing orthotic interventions, and using seating and support systems ${ }^{51}$.

Recent studies show that the mobilization and utilization of fat and carbohydrates in skeletal muscles during exercise are normal in PD. In fact, the reduction in exercise capacity results from muscle weakness and wasting and not from a reduction of muscle glycogenolysis, even with ERT therapy ${ }^{51}(B)$.

\section{Pulmonology}

Respiratory failure is a major cause of mortality and morbidity in PDJ-A $\mathrm{A}^{10,11,17}$ (B). Approximately $60 \%$ of individuals with PDJ-A show a slight decrease in vital capacity (less than $80 \%$ of normal) and $30-40 \%$ show a moderate decrease (less than $60 \%$ of normal $)^{10,11}(\mathrm{C})$. Observational studies have shown average annual declines in FVC of $1.7 \%$ to $4.6 \%^{11}$ (B).

As PDJ-A progresses, muscles weaken and lung volume is reduced. Consequently, cough can become harmful,

Table 7. Summary of recommendations for the evaluation and rehabilitation of the musculoskeletal system in juvenile and adult patients with Pompe disease.

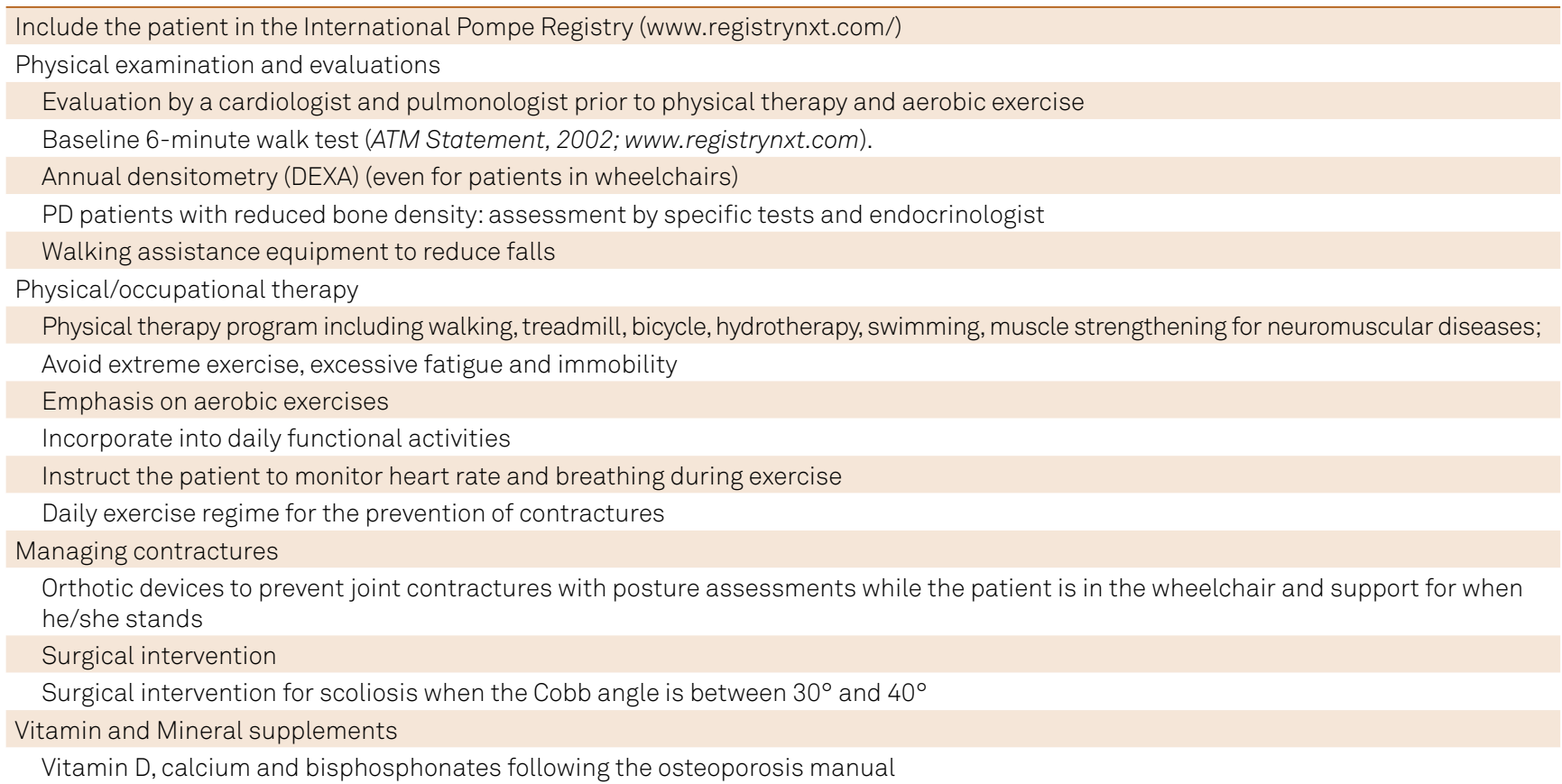


blood-gas values become abnormal, and respiratory conditions may disrupt sleep ${ }^{52,53}$.

The guidelines for monitoring and treating pulmonary aspects of PD include ${ }^{52,53}(\mathrm{C})$ :

- Clinical evaluation of respiratory status by a pulmonologist experienced in the clinical management of patients with neuromuscular diseases;

- Evaluation of pulmonary function and blood gas analysis at diagnosis, annually, at each medical visit, or as changes occur in the course of the disease;

- Update the immunization record, including influenza and pneumococcus;

- Frequent removal of secretions from the lung airways (cough devices, aspiration);

- Assess the use of the cough-assist device and train/educate patients and families about its use and muscle inhalation techniques;

- Evaluation of respiratory function during sleep if the patient feels sleepy during the day, presents with unexplained fatigue, sleep apnea, morning headaches, or when his/her vital capacity falls below 40-50\% of normal;

- Treat sleep disorders with positive airway pressure (CPAP) or with non-invasive nocturnal ventilation (BiPAP);

- In the absence of sleep studies, consider BiPAP ventilation if $\mathrm{P}_{\mathrm{CO} 2}$ is $\geq 45 \mathrm{~mm} \mathrm{Hg}$, or supine forced vital capacity $<50 \%$ of predicted, or negative forced inspiration $<60 \mathrm{~cm} \mathrm{H}_{2} \mathrm{O}$, or oxygen saturation is $<88 \%$ for more than 05 continuous minutes during sleep;

- Aggressive treatment against all lung infections, and concomitant diseases sucah as asthma and cardiomyopathy;

- Consider enzyme replacement therapy with recombinant human GAA.

For pregnant PD women clinical caution is vital regarding the pulmonary and muscle functions (see 7.4 Pregnancy, lactation and enzyme replacement therapy).

\section{Nutritional and gastrointestinal evaluation and treatment}

PD patients have difficulty swallowing and eating. Factors contributing to this difficulty include facial hypotonia, macroglossia, weakened tongue muscles, and impairment of oral movements. Patients have difficulty dealing with saliva and secretions usually accumulate on the vocal cords, which can also lead to respiratory complications. They experience fatigue of the jaw muscles as well as difficulty chewing and eating certain foods. For these reasons, patients with PD often consume low amounts of vitamins, minerals and energy, resulting in malnutrition and the compensatory use of muscle proteins, in addition to increased risk of microaspirations and aspiration pneumonia by vomiting or regurgitation. Also, nutritional problems arising from gastrointestinal muscle weakness may also be present, including dysphagia, gastroesophageal reflux, gastroparesis, and decreased bowel movements leading to constipation.
Patients should be assisted by a group of professionals that includes: a speech therapist, a stomal therapist, a psychologist, a dietitian and a nutrition specialist (preferably with experience in metabolic diseases) to ensure proper nutritional care. Diets and food consistency should be reassessed regularly.

For patients with PDJ-A, the main goal of the diet - other than adequate nutrition - is to control glycogen accumulation and the processing of amino acids. We recommend a high protein diet (20-25\% of total energy intake from protein, $30-35 \%$ from carbohydrates and $35-40 \%$ from lipids), with special attention to vitamins and minerals, and modification of food consistency. Diets rich in protein and/or L-alanine and low in carbohydrates have shown positive results in PDJ-A. Supplement with $1.4 \mathrm{~g}$ of L-Alanine up to 04 times a day is indicated if the recommended protein content associated with $4 \%$ (500 ml) of branched-chain amino acids cannot be met. Results are optimized with training and physical activity. Body composition measurements include body mass index $\left(\mathrm{kg} / \mathrm{m}^{2}\right)$ calculation, waist circumference and/or plicometry and Dual-energy X-ray absorptiometry (DXA).

Approaches to gastrointestinal problems include postural swallowing techniques, swallowing maneuvers to improve facial muscle coordination (supraglottic, Mendelsohn maneuver), environmental modifications, and oral sensory awareness techniques. The use of a feeding tube (nasal tube, gastrostomy or gastrojejunostomy tube) should also be considered.

\section{Swallowing}

In PD patients with dysphagia, positive results have been obtained with a soft diet consisting of purees and similar preparations, and including the use of thickeners.

Percutaneous endoscopic gastrostomy (PEG) is a surgical endoscopic procedure that aims to provide extended food access for patients with an intact and functional gastrointestinal tract, but who are unable to maintain adequate oral energy intake ${ }^{54}$. PEG is indicated for PDJ-A patients with severe dysphagia, aspiration risk, weight loss ( $>10 \%$ in one year) and FVC $<40 \%{ }^{54}$. The Brazilian Ministry of Health established (Portaria GM/MS No. 343e No. 120) mechanisms for the implementation of assistance centers and high complexity reference centers for nutritional therapy as part of SUS (Sistema Único de Saúde), and established their technical and operational requirements (procedure code 98.003.02-0). Gastrostomy involves a laparotomy and often general anesthesia, which limits its use in patients with severe PDJ-A (see Anesthesia/Surgery). The main indication of PEG in daily clinical practice is for longterm enteral nutrition for patients with dysphagia ${ }^{54}$.

\section{Anesthesia/surgery}

The medical staff must carefully attend to a series of considerations when indicating surgery to patients with $\mathrm{PD}$, because the increase risk of complications involving anesthesia ${ }^{55}(\mathrm{~B} / \mathrm{C})$. 
Patients with neuromuscular diseases due to metabolic causes may have a higher risk of adverse events to general anesthetics, especially the combination of halothane and succinylcholine ${ }^{55}$.

The following guidelines are recommended for surgery procedures in PDJ-A:

- Conduct anesthetic procedures only when necessary;

- Consolidate all surgical procedures requiring anesthesia to reduce the risk of exposure to the anesthetic;

- Avoid tracheal intubation and, if indicated, make sure it is performed by an experienced professional;

- Conduct rigorous intraoperative supervision;

- Use inhalation agents in non-severe patients;

- Avoid depolarizing agents due to the risk of severe hyperkalemia;

- Monitor circulating fluid volume;

- Whenever possible, perform surgery in centers with professionals experienced with PD.

\section{Family history and genetic counseling}

PD is an autosomal recessive disease caused by pathogenic mutations in both alleles of the $G A A$ gene ${ }^{1,7}$. Parents of individuals with $\mathrm{PD}$ are healthy obligatory heterozygotes with a risk of $\mathrm{PD}$ recurrence in their future offspring of approximately 25\%. Therefore, once an individual is diagnosed with $\mathrm{PD}$, it is essential for parents to receive genetic counseling. The diagnosis of an individual with PD justifies the active search of the disease among his/ her siblings. Asymptomatic or mildly symptomatic cases are often identified due to the intrafamilial clinical variability observed between two siblings with PD. Laboratory screening and diagnostic methods are the same as for the index case (Table 4).

Individuals with PDJ-A have benefited from ERT, with increased survival rates. As a result, some of them may have families once they reach reproductive age, especially those who are mildly symptomatic or diagnosed with late PD. An individual with PD can have an affected child if his/her partner is heterozygous for mutations in the gene that causes the disease. Pregnant women with PD require intensive supervision (see Pregnancy).

\section{Acknowledges}

The authors would like to acknowledge Genzyme, Sanofi Company, for the organization of the participants' logistics, as travel and accommodations, what make this work possible. The authors have full responsibility for the information contained in this text, with total exemption of the sponsors.

\section{References}

1. Hirschhorn R, Reuser AJ. Glycogen storage disease type II: acid alpha-glucosidase (acid maltase) deficiency. In: Scriver CR, Beaudet A, Sly WS, Valle D, editors. The metabolic and molecular bases of inherited disease. 8th ed. New York: McGraw-Hill; 2001. p. 3389-420.

2. American Association of Neuromuscular \& Electrodiagnostic Medicine. Diagnostic criteria for Late-Onset (Childhood and Adult) Pompe Disease. Muscle Nerve. 2009;40(1):149-60. doi:10.1002/mus.21393

3. Scott CR, Elliott S, Buroker N, Thomas LI, Keutzer J, Glass M et al. Identification of infants at risk for developing Fabry, Pompe, or mucopolysaccharidosis-I from newborn blood spots by tandem mass spectrometry. J Pediatr. 2013;163(2):498-503. doi:10.1016/j.jpeds.2013.01.031

4. Liao HC, Chiang CC, Niu DM, Wang CH, Kao SM, Tsai FJ et al. Detecting multiple lysosomal storage diseases by tandem mass spectrometry: a national newborn screening program in Taiwan. Clin Chim Acta. 2014;431:80-6.

5. Werneck LC, Lorenzoni PJ, Kay CSK, Scola RH. Muscle biopsy in Pompe disease. Arq. Neuropsiquiatr. 2013;71(5):284-9. doi:10.1590/0004-282X20130022

6. Ploeg AT, Reuser AJ. Pompe's disease. Lancet. 2008;372(9646):1342-53. doi:10.1016/S0140-6736(08)61555-X

7. Kroos M, Hoogeveen-Westerveld M, Ploeg A, Reuser AJJ. The genotype-phenotype correlation in Pompe disease. Am J Med Genet C Semin Med Genet. 2012;160C(1):59-68. doi:10.1002/ajmg.c.31318

8. Raben N, Ralston E, Chien YH, Baum R, Schreiner C, Hwu WL et al. Differences in the predominance of lysosomal and autophagic pathologies between infants and adults with Pompe disease: implications for therapy. Mol Genet Metab. 2010;101(4):324-33. doi:10.1016/j.ymgme.2010.08.001
9. Van der Beek NA, Hagemans ML, Reuser AJ, Hop WC, Van der Ploeg AT, Van Doorn PA et al. Rate of disease progression during long-term follow-up of patients with late-onset Pompe disease. Neuromuscul Disord. 2009;19:113-7. doi:10.1016/j.nmd.2008.11.007

10. Güngör D, Vries JM, Hop WC, Reuser AJ, Doorn PA, Ploeg AT et al. Survival and associated factors in 268 adults with Pompe disease prior to treatment with enzyme replacement therapy. Orphanet J Rare Dis. 2011;6(1):34. doi:10.1186/1750-1172-6-34

11. Alejaldre A, Diaz-Manera J, Ravaglia S, Tibaldi EC, D’Amore F, Morís G et al. Trunk muscle involvement in late-onset Pompe disease: Study of thirty patients. Neuromuscul Disord. 2012;22(Suppl 2):S148-54. doi:10.1016/j.nmd.2012.05.011

12. Ravaglia S, Moglia A, Garaghani KS, Danesino C. Ptosis in Pompe disease: common genetic background in infantile and adult series. J Neuroophthalmol. 2010;30(4):389-90. doi:10.1097/WNO.0b013e3181f9a923

13. Dubrovsky A, Corderi J, Lin M, Kishnani PS, Jones HN. Expanding the phenotype of late-onset pompe disease: tongue weakness: a new clinical observation. Muscle Nerve. 2011;44(6):897-901. doi:10.1002/mus.22202

14. Hobson-Webb LD, Jones HN, Kishnani PS. Oropharyngeal dysphagia may occur in late-onset Pompe disease, implicating bulbar muscle involvement. Neuromuscul Disord.. 2013;23:319-23. doi:10.1016/j.nmd.2012.12.003

15. Beek NA, Verschuure H, Reuser AJ, Ploeg AT, Doorn PA, Poublon RM. Hearing in adults with Pompe disease. J Inherit Metab Dis. 2012;35:335-41. doi:10.1007/s10545-011-9396-3

16. Güngör D, Schober AK, Kruijshaar ME, Plug I, Karabul N, Deschauer $\mathrm{M}$ et al. Pain in adult patients with Pompe disease: 
a cross-sectional survey. Mol Genet Metab. 2013;109(4):371-6. doi:10.1016/j.ymgme.2013.05.021

17. Fuller DD, EIMallah MK, Smith BK et al. The respiratory neuromuscular system in Pompe disease. Respir Physiol Neurobiol. 2013;189:241-9. doi:10.1016/j.resp.2013.06.007

18. Müller-Felber W, Horvath R, Gempel Ket al. Late onset Pompe disease: Clinical and neurophysiological spectrum of 38 patients including long-term follow-up in 18 patients. Neuromuscul Disord. 2007;17(9-10):698-706. doi:10.1016/j.nmd.2007.06.002

19. Hoeksma M, Boon M, Niezen-Koning KE, Overbeek-van Gils L, Spronsen FJ. Isolated elevated serum transaminases leading to the diagnosis of asymptomatic Pompe disease Eur J Pediatr. 2007;166:871-4. doi:10.1007/s00431-006-0315-9

20. Carlier RY, Laforet P, Wary C, Mompoint D, Laloui K, Pellegrini N et al. Whole-body muscle MRI in 20 patients suffering from late onset Pompe disease: Involvement patterns. Neuromuscul Disord. 2011;21:791-9. doi:10.1016/j.nmd.2011.06.748

21. Forsha D, Li JS, Smith PB, Ploeg AT, Kishnani P, Pasquali SK. Cardiovascular abnormalities in late-onset Pompe disease and response to enzyme replacement therapy. Genet Med. 2011;13(7):625-31. doi:10.1097/GIM.0b013e3182142966

22. Wens SC, Kuperus E, Mattace-Raso FUS, Kruijshaar ME, Brusse E, Montfort KC et al. Increased aortic stiffness and blood pressure in non-classic Pompe disease. J Inherit Metab Dis. 2014;37(3):391-7. doi:10.1007/s10545-013-9667-2

23. Sacconi S, Bocquet JD, Chanalet S, Tanant V, Salviati L, Desnuelle C. Abnormalities of cerebral arteries are frequent in patients with late-onset Pompe disease. J Neurol. 2010;257(10):1730-3. doi:10.1007/s00415-010-5618-0

24. Roberts M, Kishnani PS, Ploeg AT, Müller-Felber W, Merlini L, Prasad S et al. The prevalence and impact of scoliosis in Pompe disease: lessons learned from the Pompe Registry. Mol Genet Metab. 2011;104(4):574-82. doi:10.1016/j.ymgme.2011.08.011

25. Laforêt P, Doppler V, Caillaud C, Laloui K, Claeys KG, Richard $\mathrm{P}$ et al. Rigid spine syndrome revealing late-onset Pompe disease. Neuromuscul Disord. 2010;20(2):128-30. doi:10.1016/j.nmd.2009.11.006

26. Pompe Disease Diagnostic Working Group, Winchester B, Bali D et al. Methods for a prompt and reliable laboratory diagnosis of Pompe disease: report from an international consensus meeting. Mol Genet Metab. 2008;93(3):275-81. doi:10.1016/j.ymgme.2007.09.006

27. Müller KB, Rodrigues MD, Pereira VG, Martins AM, D’Almeida V. Reference values for lysosomal enzymes activities using dried blood spots samples: a Brazilian experience. Diagn Pathol. 2010;5(1):65-9. doi:10.1186/1746-1596-5-65

28. Llerena Jr JC, Horovitz DDG, Marie SKN, Porta G, Giuglian R, Muños Rojas MV et al. The Brazilian consensus on the management of Pompe disease. J. Pediatrics. 2009;155(4):S47-56. doi:10.1016/j.jpeds.2009.07.006

29. Vissing J, Lukacs Z, Straub V. Diagnosis of Pompe disease: muscle biopsy vs blood-based assays. JAMA Neurol. 2013;70(7):923-7. doi:10.1001/2013.jamaneurol.486

30. Oba-Shinjo SM, Silva R, Andrade FG, Pamer RE, Pomponio RJ, Ciociola KM et al. Pompe disease in a Brazilian series: clinical and molecular analyses with identification of nine new mutations. J Neurol. 2009;256(11):1881-90. doi:10.1007/s00415-009-5219-y

31. Bali DS, Goldstein JL, Banugaria S, Dai J, Mackey J, Rehder C et al. Predicting cross-reactive immunological material (CRIM) status in Pompe disease usingGAA mutations: Lessons learned from 10 years of clinical laboratory testing experience. Am J Med Genet C Semin Med Genet. 2012;160C(1):40-9. doi:10.1002/ajmg.c.31319

32. Kishnani PS, Goldenberg PC, DeArmey SL, Heller J, Benjamin D, Young $S$ et al. Cross-reactive immunologic material status affects treatment outcomes in Pompe disease infants. Mol Genet Metab. 2010;99(1):26-33. doi:10.1016/j.ymgme.2009.08.003
33. Patel TT, Banugaria SG, Case LE, Wenninger S, Schoser B, Kishnani PS. The impact of antibodies in late-onset Pompe disease: a case series and literature review. Mol Genet Metab. 2012;106(3):301-9. doi:10.1016/j.ymgme.2012.04.027

34. Hagemans ML, Winkel LP, Hop WC, Reuser AJ, Van Doorn PA, Van der Ploeg AT et al. Disease severity in children and adults with Pompe disease related to age and disease duration. Neurology. 2005;64(12):2139-41. doi:10.1212/01.WNL.0000165979.46537.56

35. Ploeg AT, Clemens PR, Corzo D, Escolar DM, Florence J, Groeneveld GJ et al. A randomized study of alglucosidase alfa in lateonset Pompoe disease. N Engl J Med. 2010;362(15):1396-406. doi:10.1056/NEJMoa0909859

36. Güngör D, Kruijshaar ME, Plug I, D’Agostino RB, Hagemans $M L$, Doorn PA et al. Impact of enzyme replacement therapy on survival in adults with Pompe disease: results from a prospective international observational study Orphanet J Rare Dis. 2013;8(1):49. doi:10.1186/1750-1172-8-49

37. Toscano A, Schoser B. Enzyme replacement therapy in lateonset Pompe disease: a systematic literature review.J Neurol. 2013;260(4):951-9. doi:10.1007/s00415-012-6636-x

38. Vries JM, Beek NAME, Hop WCJ, Karstens FPJ, Wokke JH, Visser M et al. Effect of enzyme therapy and prognostic factor in 69 adults with Pompe disease: an open label single-center study. Orphanet J Rare Dis. 2012;7(1):73. doi:10.1186/1750-1172-7-73

39. Desnick RJ, Schuchman EH. Enzyme replacement therapy for lysosomal diseases: lessons from 20 years of experience and remaining challenges. Annu Rev Genomics Hum Genet. 2012;13(1):307-35. doi:10.1146/annurev-genom-090711-163739

40. Cupler EJ, Berger KI, Leshner RT et al. Consensus treatment recommendations for late-onset Pompe disease. Muscle Nerve. 2012;45(3):319-33. doi:10.1002/mus.22329

41. Wang RY, Bodamer OA, Watson MS, Wilcox WR, ACMG Work Group on Diagnostic Confirmation of Lysosomal Storage Diseases. Lysosomal storage diseases: diagnostic confirmation and management of presymptomatic individuals. Genet Med. 2011;13(5):457-84. doi:10.1097/GIM.0b013e318211a7e1

42. Messinger YH, Mendelsohn NJ, Rhead W, Dimmock D, Hershkovitz E, Champion M et al. Successful immune tolerance induction to enzyme replacement therapy in CRIM-negative infantile Pompe disease. Genet Med. 2012;14(1):135-42. doi:10.1038/gim.2011.4

43. Politei JM. Treatment with agalsidase beta during pregnancy in Fabry disease. J Obstet Gynaecol Res. 2010;36(2):428-9. doi:10.1111/j.1447-0756.2009.01164.x

44. Vries JM, Brugma JD, Ozkan L, Steegers EA, Reuser AJ, Doorn PA et al. First experience with enzyme replacement therapy during pregnancy and lactation in Pompe disease. Mol Genet Metab. 2011;104(4):552-5. doi:10.1016/j.ymgme.2011.09.012

45. Zagnoli F, Leblanc A, Blanchard C. Pregnancy during enzyme replacement therapy for late-onset acid maltase deficiency. Neuromuscul Disord. 2013;23(2):180-1. doi:10.1016/j.nmd.2012.11.006

46. Karabul N, Berndt J, Kornblum C et al. Pregnancy and delivery in women with Pompe disease. Mol Genet Metab. 2014;112(2):148-53. doi:10.1016/j.ymgme.2014.03.010

47. Norwood F, Rudnick-Schöneborn S. 179th ENMC International Workshop: pregnancy in woman with neuromuscular disorders 5-7 November, Naarden, The Netherlands. Neuromuscul Disord. 2012;22(2):183-90. doi:10.1016/j.nmd.2011.05.009

48. World Health Organization. International classification of functioning, disability and health. Geneva: World Health Organization; 2001.

49. Angelini C, Semplicini C, Ravaglia S, Moggio M, Comi GP, Musumeci $O$ et al. New motor outcome function measures in evaluation of lateonset Pompe disease before and after enzyme replacement therapy. Muscle Nerve. 2012;45(6):831-4. doi:10.1002/mus.23340 
50. Terzis G, Dimopoulos F, Papadimas GK et al, Effect of aerobic and resistance exercise training on late-onset Pompe disease patients receiving enzyme replacement therapy. Mol Genet Metab. 2011;104(3):279-83. doi:10.1016/j.ymgme.2011.05.013

51. Case LE, Kishnani PS. Physical therapy management of Pompe disease. Genet Med. 2006;8(5):318-27. doi:10.1097/01.gim.0000217789.14470.c5

52. Mellies U, Stehling F, Dohna-Schwake C, Ragette R, Teschler $H$, Voit T. Respiratory failure in Pompe disease: treatment with noninvasive ventilation.. Neurology. 2005;64(8):1465-7. doi:10.1212/01.WNL.0000158682.85052.C0
53. Mellies U, Lofaso F. Pompe disease: a neuromuscular disease with respiratory muscle involvement. Respir Med. 2009;103(4):477-84. doi:10.1016/j.rmed.2008.12.009

54. Gauderer MW. Percutaneous endoscopic gastrostomy and the evolution of contemporary long-term enteral access. Clin Nutr. 2002;21(2):103-doi:10. doi:10.1054/clnu.2001.0533

55. Lehberger J, Roth R, Weingärtner K, Heesen M. Pompe disease: anesthesiological special features. Anaesthesist;.2012;61(3):229-33. doi:10.1007/s00101-012-1998-0 


\section{Erratum}

Arquivos de Neuro-Psiquiatria. 2016;74(2):166-76. doi:10.1590/0004-282X20150194

The citation numbers and the references were modified, as shown below:

\begin{tabular}{|c|c|c|c|}
\hline & should be & & should be \\
\hline 9 & 4 & 35 & 30 \\
\hline 10 & 5 & 36 & 31 \\
\hline 11 & 6 & 37 & 32 \\
\hline 12 & 7 & 38 & 33 \\
\hline 13 & 8 & 39 & 34 \\
\hline 14 & 9 & 40 & 35 \\
\hline 15 & 10 & 41 & 36 \\
\hline 16 & 11 & 42 & 37 \\
\hline 17 & 12 & 43 & 38 \\
\hline 18 & 13 & 44 & 39 \\
\hline 19 & 14 & 45 & 40 \\
\hline 20 & 15 & 46 & 41 \\
\hline 21 & 16 & 47 & 42 \\
\hline 22 & 17 & 48 & 43 \\
\hline 23 & 18 & 49 & 44 \\
\hline 24 & 19 & 50 & 45 \\
\hline 25 & 20 & 51 & 46 \\
\hline 26 & 21 & 52 & 47 \\
\hline 27 & 22 & 53 & 49 \\
\hline 28 & 23 & 54 & 50 \\
\hline 29 & 24 & 55 & 51 \\
\hline 30 & 25 & 56 & 52 \\
\hline 31 & 26 & 57 & 53 \\
\hline 32 & 27 & 59 & 54 \\
\hline 33 & 28 & 60 & 55 \\
\hline 34 & 29 & & \\
\hline
\end{tabular}

\section{Excluded references:}

4 to 8 and 58 .

\section{New reference:}

48. World Health Organization. International classification of functioning, disability and health. Geneva: World Health Organization; 2001. 